\title{
Peningkatan Rasa Percaya Diri dan Prestasi Belajar Peserta Didik melalui Strategi Pembelajaran Time Token Kelas IV SD Negeri 2 Kotayasa
}

\section{Gita Prili Purwani $^{1}$, Aji Heru Muslim² \& Agung Nugroho ${ }^{3}$}

Program Studi PGSD, Universitas Muhammadiyah Purwokerto, Indonesia

$\bowtie$ E-mail: gitaprili012@gmail.com

\begin{abstract}
Abstrak
Penelitian ini bertujuan untuk meningkatkan Rasa Percaya Diri dan Prestasi Belajar pada peserta didik melalui Strategi Pembelajaran Time Token di Kelas IV SD Negeri 2 Kotayasa. Metode penelitian ini menggunakan penelitian tindakan kelas. PTK ini dilakukan selama 1 siklus dan satu pertemuan. Pembelajaran ini di lakukan sesuai dengan RPP (rencana pelaksanaan pembelajaran). Penelitian ini dirancang dari beberapa tahapan yaitu perencanaan (planning), tindakan (action), observasi (observation), dan refleksi (reflection). Subjek dari penelitian ini yaitu kelas IV A SD N 2 Kotayasa dengan jumlah siswa kelas IV A yaitu 26 peserta didik. terdiri 12 anak lai-laki dan 14 perempuan. Alat pengumpulan data penelitian ini menggunakan teknik tes dan teknik non tes yaitu Observasi ( lembar observasi aktivitas guru, lembar observasi aktivitas peserta didik. lembar observasi sikap percaya diri), angket, dokumen. Hasil PTK ini dengan satu siklus menghasilkan peningkatan sikap rasa percaya diri peserta didik di kelas IV SD N 2 Kotayasa. Peserta didik. Pada siklus I dengan presentase ketuntasan belajar Bahasa Indonesia 50\% dengan kriteria cukup, ketuntasan belajar PPKn 73\% dengan kriteria baik, dan ketuntasan belajar IPS 69\% dengan kriteria baik. Hasil penelitian ini membuktikan bahwa pembelajaran menggunakan strategi time token dapat meningkatkan prestasi belajar dan percaya diri peserta didik.
\end{abstract}

Kata Kunci: Rasa percaya diri; Prestasi belajar; Time token.

\begin{abstract}
The aim of the research was to improve Confidence and Learning Achievement on students through Time Token Learning Strategies in the grade IV of Private Primary School 2 Kotayasa. This research method used Classroom Action Research. This CAR was carried out for 1 cycle and one meeting. This learning was carried out in accordance with the lesson plan (learning implementation plan). This research was designed from several stages, namely planning, action, observation, and reflection. The subject of this research were students of class IVA Private Primary School 2 Kotayasa with the number of class IVA were 26 students. There were 12 male students and 14 female students. The data collection of the research used test techniques and non-test techniques, namely Observation (teacher activity observation sheet, student activity observation sheet and Confidence attitude observation sheet), questionnaire, document. The results of this CAR with one cycle and one meeting could produce the increase of students' self-confidence in class IV Private Primary School 2 Kotayasa. Learners In the first cycle with the percentage of completeness learning Indonesian Language was $50 \%$ with sufficient criteria, Civic education was $73 \%$ with good criteria, and Social Sciences was 69\% with good criteria. The result of this study prove that learning activities using a time token strategy can improve student's learning achievement and confidence.
\end{abstract}

Keywords: Self-confidence; Learning achievement; Time token. 


\section{PENDAHULUAN}

Pendidikan hingga kini masih dipercaya sebagai media yang sangat ampuh dalam membangun kecerdasan sekaligus kepribadian anak manusia menjadi lebih baik. Muhaimin (2014:9) menjelaskan bahwa pendidikan berasal dari kata "didik", lalu kata ini mendapat awalan "me" sehingga menjadi "mendidik", artinya memelihara dan memberi latihan. Pendidikan dapat diartikan sebagai sebuah proses dengan metodemetode tertentu sehingga orang memeroleh pengetahuan, pemahaman, dan cara bertingkah laku yang sesuai dengan kebutuhan. Pada proses pembelajaran keberhasilan proses belajar mengajar di kelas dipengaruhi oleh banyak faktor. Faktorfaktor tersebut antara lain guru, peserta didik, materi, serta strategi pembelajaran yang digunakan agar proses belajar mengajar terlaksana dengan baik dan dapat mencapai sasaran.

Tinjauan di SD N 2 Kotayasa pada hari sabtu tanggal 07 Desember 2019 ada beberapa faktor yang menyebabkan kurangnya keberhasilan peserta didik yaitu kurangnya rasa percaya diri pada saat proses pembelajaran berdiskusi seringkali peserta didik menjawab bersama-sama, namun ketika guru menunjuk salah satu peserta didik untuk menjawab peserta didik itu diam, dan pada saat guru meminta peserta didik untuk menjawab dengan angkat tangan kebanyakan peserta didik hanya diam. Ketika guru meminta peserta didik untuk maju ke depan kelas peserta didik itu membacakan jawabannya dengan suara yang pelan. Sahardita (2011:134) menyatakan bahwa rasa atau sikap percaya diri merupakan model utama bagi peserta didik untuk mewujudkan potensi yang dimiliki. Potensi tersebut ada yang sudah muncul dan ada yang belum, untuk memunculkan potensi pada diri peserta didik diperlukan modal utama berupa percaya diri, karena percaya diri tersebut akan mengantarkan peserta didik pada potensi yang dimilikinya.

Permasalahan yang ditemukan, tidak sesuai dengan indikator dari sikap percaya diri antara lain; Pantang menyerah, berani menyatakan pendapat, berani bertanya, mengutamakan usaha sendiri daripada bantuan, berpenampilan tenang. Dari permasalahan yang ditemukan peserta didik belum mencakup kriteria tersebut. Maka dari itu untuk meningkatkan sikap percaya diri peserta didik dan prestasi belajar maka diperlukan strategi pembelajaran yang mampu meningkatkan sikap percaya diri dan prestasi belajar, yaitu dengan strategi pembelajaran Time Token. Huda (2019: 239) menyatakan Strategi pembelajaran Time Token merupakan salah satu strategi yang digunakan untuk melatih dan mengembangkan keterampilan sosial agar peserta didik tidak mendominasikan pembicaraan atau diam sama sekali.

Menurut Rusman (2016: 139) pembelajaran tematik terpadu adalah pembelajaran yang dikemas dalam bentuk tema-tema berdasarkan muatan beberapa mata pelajaran yang dipadukan atau diintegrasikan.Tematik diberikan dengan maksud menyatukan konten kurikulum dalam unit-unit atau satuan-satuan yang utuh sehingga membuat pembelajaranbermakna dan mudah dipahami oleh siswa.

Merujuk pada riri-ciri pembelajaran tematik terpadu antara lain: 1) Pengalaman dan kegiatan belajar sangat relevan dengan tingkat perkembangan dan kebutuhan anak usia sekolah dasar, sehingga memberikan pengalaman langsung pada anak, 2) Kegiatan-kegiatan yang dipilih dalam pelaksanaan pembelajaran tematik bertolak dari minat dan kebutuhan siswa, juga melalui penilaian proses dan hasil belajarnya, 3) Kegiatan belajar akan lebih bermakna dan berkesan bagi siswa sehingga hasil belajar dapat bertahan lebih lama, serta bersifat luwes dengan adanya keterpaduan berbagai mata pelajaran, 4) membantu mengembangkan keterampilan berpikir siswa, 5) menyajikan kegiatan belajar yang bersifat pragmatis sesuai dengan permasalahan yang sering ditemui siswa dalam lingkungannya, 6) mengembangkan keterampilan sosial , siswa, seperti kerjasama, toleransi, komunikasi, dan tanggap terhadap gagasan orang lain. 
Karakteristik Siswa Kelas IV Sekolah Dasar. Tahapan karakteristik pada perkembangan anak yang penting dan bahkan fendumental bagi kesuksesan perkembangan selanjutnya adalah pada usia Sekolah Dasar (sekitar 6-12 tahun). Karakteristik peserta didik dikelas IV Sekolah Dasar masih termasuk dalam tahap atau fase pertumbuhan dan perkembangan. Peserta didik kelas IV sekolah dasar biasanya berumur antara 10-11 Tahun.

Menurut Jean Piaget (Yaumi, M, 170: 2014) tahap perkembangan anak ditinjau dari umur, Concrete Operational (umur 7-11 tahun) yaitu; 1) Mampu berpikir secara logis tentang objek dan kejadian, 2) Dapat berbicara tentang angka-angka, jumlah dan berat barang, 3) Mengelompokkan objek berdasarkan ciri dan dapat menyusun objek tersebut berdasarkan seri dan ukurannya.

Kelebihan Pembelajaran Tematik. Pembelajaran tematik menurut Suryosubroto (2009: 136-137) memiliki beberapa keuntungan. Keuntungan yang dimaksud, yaitu: 1) Menyenangkan karena bertolak dari minat dan kebutuhan peserta didik, 2) Pengalaman dan kegiatan belajar relevan dengan tingkat perkembangan dan kebutuhan peserta didik. 3) Hasil belajar akan bertahan lebih lama karena lebih berkesan dan bermakna, 4) Menumbuhkan keterampilan sosial, seperti bekerja sama, toleransi, komunikasi, dan tanggapan gagasan orang lain.

Hasil wawancara dengan guru kelas IV SD Negeri 2 Kotayasa pada hari Senin, 09 Desember 2019, permasalahan yang dihadapi guru kelas adalah bahwa prestasi belajar peserta didik di kelas IV masih rendah serta rasa percaya diri pada peserta didik yang masih kurang pada saat pembelajaran berlangsung. Berdasarkan hasil nilai PTS (Penilaian Tengah Semester) kelas IV A Tahun Pelajaran 2019/2020 menunjukan bahwa hasil nilai PTS (Penilaian Tengah Semester) masih rendah. Rendahnya prestasi belajar peserta didik ditunjukan dengan jumlah peserta didik 26 siswa, hanya 2 siswa yang memperoleh nilai tuntas Kriteria Ketuntasan Minimal (KKM).
Tujuan guru mengajar adalah untuk mengadakan perubahan yang dikehendaki dalam rasa peserta diri peserta didik. Perubahan yang di kehendaki guru dengan menggunakan suatu strategi pembelajaran untuk mencapai tujuan dengan memilih metode dan pendekatan yang tepat yaitu dengan strategi time token yang diharapkan dapat merubah rasa percaya diri dan prestasi belajar pada peserta didik meningkat. Strategi pembelajaran time token dapat meningkatkan rasa percaya diri peserta didik karena memberikan kesempatan berbicara untuk masing-masing peserta didik sehingga tidak ada yang mendominasi atau diam sama sekali.

Komponen utama dalam kegiatan belajar mengajar menggunakan strategi Time Token adalah siswa dan guru, dalam hal ini siswa yang menjadi subjek belajar, bukan menjadi objek belajar. Dalam keseluruhan proses pendidikan di sekolah kegiatan belajar merupakan kegiatan yang paling pokok. Berarti berhasil atau tidaknya pencapaian tujuan pendidikan banyak bergantung kepada bagaimana proses belajar yang dialami oleh siswa sebagai anak didik.

Latar belakang yang telah diuraikan sebelumnya, penelitian ini akan fokus membahas bagaimana peningkatkan rasa percaya diri pada peserta didik di kelas IV SD Negeri 2 Kotayasa menggunakan strategi time token dan bagaimana peningkatkan prestasi belajar pada peserta didik kelas IV SD Negeri 2 Kotayasa menggunakan strategi time token.

\section{METODE PENELITIAN}

Jenis penelitian ini yaitu Penelitian Tindakan Kelas (PTK) Trianto (2011:13) mengemukakan penelitian tindakan kelas berasal dari istilah bahasa Inggris Classroom Action Research, yang berarti penelitian yang dilakukan pada sebuah kelas untuk mengetahui akibat tindakan yang diterapkan pada suatu subyek penelitian dikelas tersebut. Kegiatan penelitian tindakan kelas ini dilaksanakan dikelas IV A SD Negeri 2 Kotayasa Kecamatan Sumbang, Kabupaten Bayumas. Dengan jumlah siswa kelas IV A 
yaitu 26 peserta didik. Sebanyak 12 anak merupakan siswa putra dan 14 anak siswa putri. Desain penelitian yang digunakan adalah model Kemmis dan Mc.Taggart terdiri dari empat tahapan penelitian yaitu perencanaan (Planning), tindakan (action), observasi (observation), dan refleksi (reflection).

Penelitian ini menggunakan instrumen yaitu menggunakan teknik tes dan teknik non tes yaitu Observasi ( lembar observasi aktivitas guru, lembar observasi aktivitas peserta didik. lembar observasi sikap percaya diri), angket, dokumen. Analisis data yang digunakan pada penelitian ini yaitu yaitu analisis data kualitatif dan kuantitatif.Analisis data kualitatif digunakan untuk mengukur sikap percaya diri siswa (aspek afektif) sedangkan analisis data kuantitatif digunakan untuk mengukur prestasi belajar siswa (aspek kognitif).

\section{HASIL DAN PEMBAHASAN}

Penelitian Tindakan Kelas dilaksanakan di Kelas IV SDN 2 Kotayasa, Kec. Sumbang, Kab. Banyumas pada tahun ajaran 2019/2020. Penelitian Tindakan Kelas ini dilaksanakan dalam satu siklus, satu pertemuan. Pada siklus I dan pertemuan I ini membutuhkan waktu 6 × 35 menit (6 jam pelajaran). Hasil penelitian ini dihitung dengan menggunakan data tes. Data tes yaitu berupa soal uraian terdiri dari 10 soal untuk mengetahui prestasi belajar peserta didik yang disesuaikan dengan Kompetensi Dasar dari tema 8.

\section{Angket Percaya Diri}

Hasil angket sikap percaya diri menunjukan bahwa peserta didik di SD N 02 Kotayasa pada indikator yaitu 1) Saya tidak takut jika ditunjuk oleh guru untuk menjawab pertanyaan menunjukan skor rata-rata 2,8 dengan kriteria baik, 2) Saya yakin dengan tugas yang saya kerjakan menunjukan skor rata-rata 3,9 dengan kriteria sangat baik, 3) Saya berani menyampaikan pendapat di depan kelas Ketika bapak/ibu guru memberikan kesempatan presentasi menunjukan skor rata-rata 2,4 dengan kriteria cukup, 4) saya selalu bersedia untuk presentasi menunjukan skor rata-rata 2,8 dengan kriteria baik, 5) Saya bosan jika diberi tugas/PR yang banyak menunjukan skor rata-rata 2,9 dengan kriteria baik 6) Saya bertanya kepada guru jika ada materi yang belum saya pahami menunjukan skor rata-rata 3 dengan kriteria baik, 7) Saya takut berbuat salah ketika berbuat salah dalam menyampaikan pendapat menunjukan skor rata-rata 2,8 dengan kriteria baik,8) Saya berbicara sendiri saat mendapat tugas kelompok menunjukan skor rata-rata 3,3 dengan kriteria sangat baik, 9) Saya menghargai teman yang berbeda pendapat dengan saya menunjukan skor rata-rata 3,2 dengan kriteria baik, 10) Siap berdiskusi dengan teman-teman meskipun di luar jam pelajaran menunjukan skor rata-rata 2,7 dengan kriteria baik. Lebih lengkap disajikan pada tabel 1.

Tabel 1. Rekapitulasi angket rasa percaya diri

\begin{tabular}{lcc}
\hline \multicolumn{1}{c}{ Indikator } & $\begin{array}{c}\text { Rata- } \\
\text { rata }\end{array}$ & Kriteria \\
\hline $\begin{array}{l}\text { Saya tidak takut jika } \\
\text { ditunjuk oleh guru untuk }\end{array}$ & 2,5 & Baik \\
menjawab pertanyaan & & \\
\hline $\begin{array}{l}\text { Saya yakin dengan tugas } \\
\text { yang saya kerjakan }\end{array}$ & 3,9 & $\begin{array}{c}\text { Sangat } \\
\text { Baik }\end{array}$ \\
\hline $\begin{array}{l}\text { Saya berani menyampaikan } \\
\text { pendapat di depan kelas }\end{array}$ & 2,4 & Cukup \\
\hline $\begin{array}{l}\text { Ketika bapak/ibu guru } \\
\text { memberikan kesempatan } \\
\text { presentasi, saya selalu } \\
\text { bersedia untuk presentasi }\end{array}$ & & \\
\hline $\begin{array}{l}\text { Saya bosan jika diberi } \\
\text { tugas/PR yang banyak }\end{array}$ & 2,9 & Baik \\
\hline $\begin{array}{l}\text { Saya bertanya kepada guru } \\
\text { jika ada materi yang belum }\end{array}$ & 3 & Baik \\
saya pahami & & \\
\hline $\begin{array}{l}\text { Saya takut berbuat salah } \\
\text { ketika berbuat salah dalam } \\
\text { menyampaikan pendapat }\end{array}$ & & \\
\hline $\begin{array}{l}\text { Saya berbicara sendiri saat } \\
\text { mendapat tugas kelompok }\end{array}$ & 3,3 & Sangat \\
\hline $\begin{array}{l}\text { Saya menghargai teman } \\
\text { yang berbeda pendapat } \\
\text { dengan saya }\end{array}$ & 3,2 & Baik \\
\hline $\begin{array}{l}\text { Siap berdiskusi dengan } \\
\text { teman-teman meskipun di } \\
\text { luar jam pelajaran }\end{array}$ & 2,7 & \\
\hline
\end{tabular}

Dimyati \& Mudjiono (2010:245) mengungkapkan bahwa: "Rasa percaya diri 
timbul dari keinginan mewujudkan diri bertindak dan berhasil. Rasa percaya diri dilihat dari segi perkembangan dapat timbul berkat adanya pengakuan dari lingkungan. Proses belajar diketahui bahwa unjuk prestasi tahap pembuktian "perwujudan diri" yang diakui oleh guru dan rekan sejawat peserta didik. Makin sering berhasil menyelesaikan tugas, maka semakin memeperoleh pengakuan umum, dan selanjutnya rasa percaya diri semakin kuat".

Percaya diri menurut Salirawati (2012: 218) mengemukakakan bahwa "siswa yang memiliki tingkat kepercayaan diri yang baik ditandai dengan keyakinan akan kemampuan dirinya, karena tanpa rasa percaya diri akan sulit mencapai prestasi yang optimal". Perwujudan adalah keinginan diri seseorang dalam menggunakan segala kemampuan yang ada pada dirinya dalam mencapai apapun yang diinginkan dan yang bisa dilakukan. Definisi lain juga dikemukakan oleh Elfiky (2015: 54) adalah berbuat dengan penuh keyakinan dan mendorong seseorang untuk maju dan berkembang serta selalu memperbaiki diri.

Mulyasa (2014:147) mengatakan ciri-ciri individu yang dapat dijadikan sebagai indikator percaya diri yaitu : 1) Pantang Menyerah, 2) Berani menyatakan pendapat, 3) Berani bertanya, 4) Mengutamakan usaha sendiri daripada bantuan, 5) Berpenampilan tenang.

Hasil temuan dari angket sikap percaya diri pada peserta didik di kelas IV SD N 01 Kotayasa dari tiap indikator sebagai berikut: 1) Saya tidak takut jika ditunjuk oleh guru untuk menjawab pertanyaan dengan nilai rata-rata 2,8 dengan kriteria baik, 2) Saya yakin dengan tugas yang saya kerjakan menunjukan skor rata-rata 3,9 dengan kriteria sangat baik, 3) Saya berani menyampaikan pendapat di depan kelas Ketika bapak/ibu guru memberikan kesempatan presentasi menunjukan skor rata-rata 2,4 dengan kriteria cukup, 4) saya selalu bersedia untuk presentasi menunjukan skor rata-rata 2,8 dengan kriteria baik, 5) Saya bosan jika diberi tugas/PR yang banyak menunjukan skor rata-rata 2,9 dengan kriteria baik 6)
Saya bertanya kepada guru jika ada materi yang belum saya pahami menunjukan skor rata-rata 3 dengan kriteria baik, 7) Saya takut berbuat salah ketika berbuat salah dalam menyampaikan pendapat menunjukan skor rata-rata 2,8 dengan kriteria baik, 8) Saya berbicara sendiri saat mendapat tugas kelompok menunjukan skor rata-rata 3,3 dengan kriteria sangat baik, 9) Saya menghargai teman yang berbeda pendapat dengan saya menunjukan skor rata-rata 3,2 dengan kriteria baik, 10) Siap berdiskusi dengan teman-teman meskipun di luar jam pelajaran menunjukan skor rata-rata 2,7 dengan kriteria baik. Lebih jelasnya disajikan pada gambar 1.

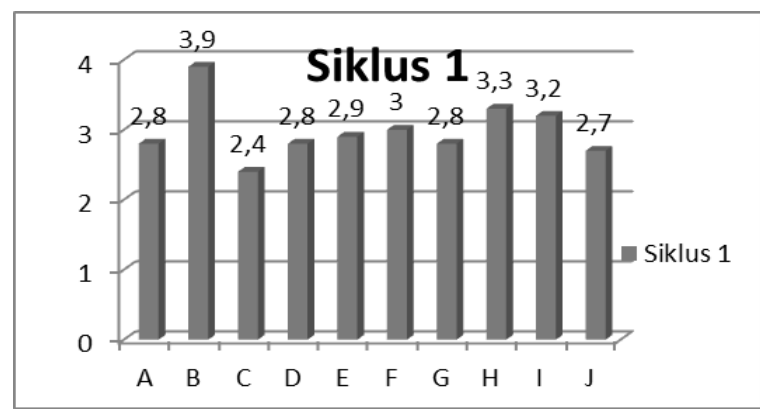

Gambar 1. Diagram hasil angket rasa percaya diri

Pembelajaran menggunakan strategi pembelajaran Time Token memberikan data bahwa dapat membantu rasa percaya diri pada peserta didik. Rasa percaya diri bagi peserta didik adalah keyakinan pada kemampuan-kemampuan sendiri, keyakinan pada adanya suatu maksud pada kehidupan dan kepercayaan bahwa dengan akal budi akan mampu melaksanakan apa yang akan diinginkan. Hal ini sesuai dengan pendapat Hakim (Marjanti, 2015 : 2) mengungkapkan Rasa percaya diri merupakan keberanian menghadapi tantangan karena memberi suatu kesadaran bahwa belajar dari pengalaman jauh lebih penting daripada keberhasilan atau kegagalan. Rasa percaya diri penting untuk berpartisipasi dalam kehidupan sosial.

Strategi Time Token yaitu strategi pembelajaran yang menggunakan keterampilan sosial dan kerjasama peserta didik agar peserta didik dapat mengungkapkan pendapatnya. Huda (2019: 239) menyatakan Strategi pembelajaran Time 
Token merupakan salah satu strategi yang digunakan untuk melatih dan mengembangkan keterampilan sosial agar peserta didik tidak mendominasikan pembicaraan atau diam sama sekali. Hal ini sesuai dengan pendapat Arends (Mauliza, 2016 : 2) strategi Time Token adalah pembelajaran kooperatif yang digunakan untuk mengembangkan keterampilan partisipasi peserta didik. Partisipasi peserta didik merupakan keterlibatan peserta didik dalam berkomunikasi dengan guru pada saat proses pembelajaran berlangsung.

Validitas data dalam penelitian tindakan kelas menggunakan triangulasi. Triangulasi menurut Sugiyono (2014 : 241) mengatakan bahwa triangulasi merupakan teknik pengumpulan data yang sifatnya menggabungkan dari berbagai teknik pengumpulan data dan sumber-sumber data yang telah ada.Pada penelitian ini menggunakan triangulasi teknik. Data yang akan di triangulasikan adalah Percaya Diri. Triangulasi teknik dilakukan dengan cara membandingkan data dan informasi dengan cara yang berbeda untuk memperoleh kebenaran informasi.

\section{Hasil Prestasi Belajar}

Hasil tes belajar peserta didik diukur menggunakan tes pada setiap pertemuan.Tes kemampuan berpikir kritis disusun sesuai dengan kompetensi dasar dan indikator pada tema 8. Lembar soal prestasi belajar terdiri dari 10 soal.

Hasil evaluasi prestasi belajar menunjukan bahwa peserta didik pada siklus I yaitu untuk prestasi belajar Bahasa Indonesia, PPKn dan IPS. Hasil Prestasi belajar Bahasa Indonesia menunjukan bahwa dari total peserta didik tuntas pada siklus I sebanyak 13 peserta didik dan jumlah peserta didik tidak tuntas 13 peserta didik dengan nilai tertinggi yaitu 88 dan nilai terendah 33 . Dari hasil tersebut presentase ketuntasan Bahasa Indonesia yang diperoleh pada siklus I yaitu $50 \%$ hal ini dapat digolongkan termasuk dalam kriteria ketuntasan Cukup.

Hasil prestasi belajar PPKn dari data rekapitulasi hasil prestasi belajar yang diperoleh peserta didik dari jumlah total peserta didik 26, peserta didik yang tuntas 19 dan jumlah peserta didik yang tidak tuntas 7 dengan nilai tertinggi yaitu 88 dan nilai terendah 33. Dari hasil tersebut presentase ketuntasan PPKn yang diperoleh pada siklus I yaitu $73 \%$ hal ini dapat digolongkan termasuk dalam kriteria ketuntasan Baik.

Hasil prestasi belajar IPS dari data rekapitulasi hasil prestasi belajar yang diperoleh peserta didik dari jumlah total peserta didik 26, peserta didik yang tuntas 18 dan jumlah peserta didik yang tidak tuntas 8 dengan nilai tertinggi 83 dan nilai terendah 42. Dari hasil tersebut presentase ketuntasan IPS yang diperoleh pada siklus I yaitu $69 \%$ hal ini dapat digolongkan termasuk dalam kriteria ketuntasan Baik. Lebih rinci dapat dilihat pada table 2 .

Tabel 2. Hasil evaluasi prestasi belajar peserta didik siklus

\begin{tabular}{llc}
\hline No & Indikator & $\begin{array}{c}\text { Siklus } \\
\text { I }\end{array}$ \\
\hline & \multicolumn{1}{c}{ Bahasa Indonesia } \\
\hline 1 & Jumlah Peserta Didik & 26 \\
2 & KKM & 70 \\
3 & Rata-rata & 60 \\
4 & Nilai tertinggi & 88 \\
5 & Nilai terendah & 33 \\
6 & Jumlah peserta didik tuntas & 13 \\
7 & Jumlah peserta didik tidak & 13 \\
& tuntas & \\
8 & Presentase ketuntasan kelas & $50 \%$ \\
9 & Rata-rata siklus I & 63 \\
10 & Presentase ketuntasan siklus I & $50 \%$ \\
\hline & Kriteria Pencapaian Siklus I & Cuku \\
& & p \\
\hline & \multicolumn{1}{c}{ PPKn } & \\
\hline 1 & Jumlah Peserta Didik & 26 \\
2 & KKM & 70 \\
3 & Rata-rata & 71 \\
4 & Nilai tertinggi & 88 \\
5 & Nilai terendah & 33 \\
6 & Jumlah peserta didik tuntas & 19 \\
7 & Jumlah peserta didik tidak & 7 \\
& tuntas & \\
8 & Presentase ketuntasan kelas & $73 \%$ \\
9 & Rata-rata siklus I & 71 \\
10 & Presentase ketuntasan siklus I & $73 \%$ \\
\hline & Kriteria Pencapaian Siklus I & Baik \\
& &
\end{tabular}




\begin{tabular}{llc}
\hline No & Indikator & $\begin{array}{l}\text { Siklus } \\
\text { I }\end{array}$ \\
\hline \multicolumn{1}{c}{ IPS } \\
\hline 1 & Jumlah Peserta Didik & 26 \\
2 & KKM & 70 \\
3 & Rata-rata & 70 \\
4 & Nilai tertinggi & 83 \\
5 & Nilai terendah & 42 \\
6 & Jumlah peserta didik tuntas & 18 \\
7 & Jumlah peserta didik tidak tuntas & 8 \\
8 & Presentase ketuntasan kelas & $69 \%$ \\
9 & Rata-rata siklus I & 70 \\
10 & Presentase ketuntasan siklus I & $69 \%$ \\
\hline 11 & Kriteria Pencapaian Siklus & Baik \\
\hline
\end{tabular}

Prestasi belajar merupakan suatu hal yang menjadi pembuktian atas apa yang telah diusahakan selama proses belajar di kelas, prestasi belajar menjadi salah satu tolak ukur keberhasilan seseorang dalam pendidikan. Prestasi belajar pada umumnya berkenaan dengan aspek pengetahuan, kata prestasi banyak digunakan dalam berbagai bidang. Arifin (2013 : 12) menjelaskan bahwa prestasi belajar merupakan suatu masalah yang bersifat perenial dalam sejarah kehidupan manusia, karena sepanjang rentang kehidupannya manusia selalu mengejar prestasi menurut bidang dan kemapuannnya masing-masing.

Hamdani (2011: 139) berpendapat bahwa prestasi belajar adalah hasil pengukuran dari penilaian usaha belajar yang dinyatakan dalam bentuk symbol, huruf maupun kalimat yang menceritakan hasil yang sudah dicapai oleh setiap anak pada periode tertentu. Pendapat lain juga dikemukakan oleh Mulyasa (2014 : 189) yang berpendapat bahwa prestasi belajar adalah hasil yang diperoleh seseorang setelah menempuh kegiatan belajar, sedangkan belajar pada hakekatnya merupakan usaha sadar yang dilakukan seseorang untuk memenuhi kebutuhannya.

Pada saat proses pembelajaran tidak semua siswa dapat menangkap apa yang dijelaskan oleh guru, sebab itu prestasi belajar siswa juga kan berbeda-beda dikarenakan adanya beberapa faktor yang mempengaruhinya baik di dalam dirinya (internal) maupun dari luar dirinya (eksternal). Seperti yang telah dijelaskan oleh Hamdani (2011: 139) bahwa pada dasarnya faktor yang mempengaruhi prestasi belajar dapat digolongkan menjadi dua bagian, yaitu faktor dari dalam (intern) dan faktor dari luar (ekstern). Kedua faktor tersebut antara lain:

\section{Faktor internal}

Faktor internal menurut Hamdani (2011: 139) adalah faktor yang berasal dari peserta didik. faktor ini antara lain sebagai berikut; a) Kecerdasan kesanggupan jiwa untuk menghadapi dan mengatasi kesulitankesulitan baru dengan sadar, dengan berfikir cepat dan tepat, b) Faktor jasmani atau fisiologis pada umumnya sangat berpengaruh terhadap kemampuan belajar seseorang, c) Sikap adalah segala perbuatan dan tindakan yang berdasarkan pada pendirian dan keyakinan yang dimiliki, d) Minat adalah suatu perangkat mental yang terdiri dari suatu campuran dari perasaan, harapan, pendirian, prasangka, rasa takut atau kecenderungan lain yang mengarahkan individu kepada suatu pikiran tertentu, e) Bakat merupakan kemampuan potensial yang dimiliki seseorang untuk mencapai keberhasilan pada masa yang akan dating, f) Motivasi adalah segala sesuatu yang mendorong peserta didik untuk melakukan sesuatu yang lebih baik lagi.

\section{Faktor eksternal}

Faktor eksternal meliputi; a) Keadaan keluarga, mempengaruhi belajar pada peserta didik, karena keluarga sangat berperan penting, keluarga merupakan madrasah pertama bagi peserta didik.Faktor yang mempengaruhi belajar mencakup cara orangtua mendidik, hubungan antara orangtua dan anak, keharmonisan keluarga, b) Keadaan sekolah merupakan tempat dimana peserta didik menghabiskan waktunya untuk belajar. Faktor yang mempengaruhi belajar ini mencakup cara guru dalam mengajar, keadaan sekolah, suasana sekolah, hubungan antara peserta didik dengan teman sejawat, c) Lingkungan masyarakat, dapat mempengaruhi belajar peserta didik karena keberadaan peserta didik 
dilingkungan masyarakat. Faktor yang mempengaruhi belajar ini membahas tentang kegiatan peserta didik dilingkungan masyarakat.

Hasil ketuntasan prestasi belajar pada peserta didik siklus I di kelas IV SD N 02 Kotayasa dari tiga mata pelajaran Bahasa Indonesia dengan nilai rata-rata 50\% dengan kriteria cukup, hal ini karena peserta didik pada saat pembelajaran berlangsung masih ragu dan sering diam pada saat guru memberikan kesempatan bicara. Masih belum paham bagaimana cara menggunakan kupon yang sudah diberikan guru. Pada mata pelajaran PPKn dengan nilai rata-rata $73 \%$ dengan kriteria baik, hal ini karena peserta didik cenderung sudah berani untuk bertanya, menjawab pertanyaan dan memaparkan hasil diskusinya didepan kelas. Dan mata pelajaran IPS dengan nilai rata-rata $69 \%$ dengan kriteria baik. Lebih jelas pada gambar 2.

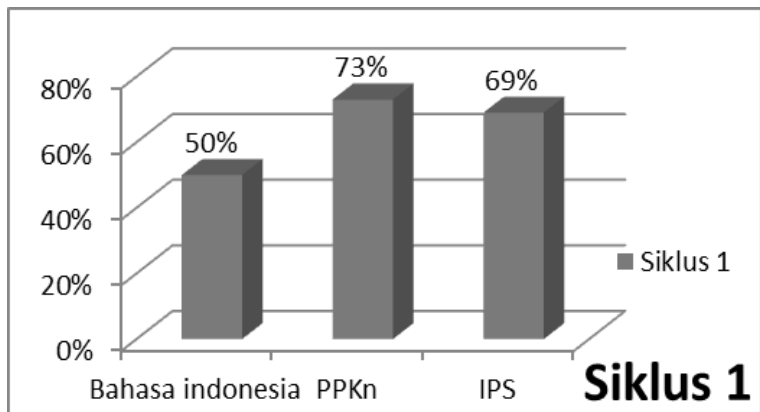

Gambar 2. Diagram hasil ketuntasan belajar siklus I

Gambar 2. menunjukkan jika menggunakan strategi pembelajaran Time Token secara bertahap prestasi peserta didik pasti akan meningkat dan memenuhi kriteria, peserta didik di kelas IV SD N 02 Kotayasa sudah baik dalam ketuntasan prestasi belajar. Kehadiran prestasi belajar dalam kehidupan manusia pada tingkat dan jenis tertentu dapat memberikan kepuasan tersendiri pada manusia, karena mempunyai beberapa fungsi utama seperti yang dikemukakan Arifin (2013: 12) antara lain: 1) Prestasi belajar sebagai indikator kualitas dan kuantitas pengetahuan yang telah dikuasai peserta didik, 2) Prestasi belajar sebagai lambang pemuasan hasrat ingin tahu dan merupakan kebutuhan umum manusia, 3) Sebagai bahan informasi dalam inovasi pendidikan., 4) Prestasi belajar sebagai indikator itern dan ekstern dari suatu institusi pendidikan., 5) Prestasi belajar dapat dijadikan indikator terhadap daya serap anak didik.

Pernyataan tersebut dapat dipahami betapa pentingnya untuk mengetahui prestasi belajar peserta didik, baik secara individu maupun kelompok.Karena dalam fungsi prestasi tidak hanya sebagai indikator keberhasilan dalam bidang studi tertentu tetapi juga sebagai indikator kualitas pendidikan. Disamping itu prestasi belajar juga berguna sebagai umpan balik bagi guru dan peserta didik dalam melaksanakan proses belajar mengajar.

\section{KESIMPULAN}

Berdasarkan Hasil Penelitian Tindakan Kelas (PTK) yang telah dilaksanakan dalam upaya meningkatkan rasa percaya diri dan prestasi belajar pada peserta didik di kelas IV SD N 02 Kotayasa melalui strategi pembelajaran Time Token dapat terlihat pada penelitian siklus I pada tema 8 "Daerah Tempat Tinggalku" maka dapat disimpulkan: 1) Penerapan strategi pembelajaran Time Token terlihat mampu untuk meningkatkan rasa percaya diri pada peserta didik di kelas IV SD N 02 Kotayasa. Hal ini dapat dibuktikan dari dalam proses pembelajaran peserta didik lebih aktif dalam melaksanakan pembelajaran dan berani menyatakan pendapatnya. Hal ini sesuai dengan indikator rasa percaya diri yaitu pantang menyerah, berani menyatakan pendapatnya, berani bertanya, mengutamakan usaha sendiri daripada bantuan, dan berpenampilan tenang.

Strategi pembelajaran Time Token ini juga dibantu oleh media pembalajaran yaitu "Kupon Bernyawa" media tersebut sebagai bukti yang dapat terlihat oleh guru dan peneliti bagaimana peserta didik aktif dalam pembelajaran yang sedang berlangsung menggunakan strategi pembelajaran Time Token. Strategi ini mampu meningkatkan rasa percaya diri pada peserta didik diperkuat dengan adanya data yang diperoleh yaitu dibuktikan dengan nilai rata-rata siklus I mencapai kriteria baik, 2) Penerapan strategi 
pembelajaran Time Token dapat terlihat mampu meningkatkan prestasi belajar peserta didik. Hal ini dapat dibuktikan dengan hasil evaluasi belajar yang diperoleh peserta didik pada siklus I dengan presentase ketuntasan belajar Bahasa Indonesia 50\% dengan kriteria cukup, ketuntasan belajar PPKn $73 \%$ dengan kriteria baik, dan ketuntasan belajar IPS 69\% dengan kriteria baik.

\section{DAFTAR RUJUKAN}

Anshory, I., Saputra, S., \& Amelia, D. (2018). Pembelajaran Tematik Integratif Pada Kurikulum.2013 Kelas Rendah SD Muhammadiyah 07 Wajak. Jurnal Inovasi Pembelajaran, 4(1): 35-46.

Arifin, Z. (2013). Evaluasi Pembelajaran . Bandung: PT Remaja Rosdakarya.

Arikunto, S., \& Cepi, S. A. J. (2010). Evaluasi Program Pendidikan. Jakarta: PT Bumi Aksara.

Dimyati dan Mudjiono, (2010).Belajar dan Pembelajaran. Jakarta: PT Rineka Cipta.

Elfiky, I. (2015). Terapi Berpikir Positif .Jakarta: Nusantara Lestari Ceria Pratama.

Marjanti, S. (2015). Upaya Meningkatkan rasa percaya diri melalui konseling kelompok bagi siswa X IPS 6 SMA 2 Bae Kudus Tahun Pelajaran 2014-2015. Jurnal Konseling GUSJIGANG, Vol. 1, (2) . 1-11.

Mauliza, W. (2016). Pengaruh Model Pembelajaran Kooperatif Tipe Time
Token Arends terhadap Hasil Belajar Siswa Pada materi sistem Pernapasan di SMA Negeri 5 Banda Aceh. Jurnal Ilmiah Mahasiswa Pendidikan Biologi, Vol. 1, (1). 1-9.

Miftahul, H. (2016). Model-model Pengajaran dan Pembelajaran. Yogyakarta: Pustaka Pelajar.

Muhaimin, A. (2014). Pendidikan yang Membebaskan. Jogjakarta: Ar-Ruzz Media.

Mulyasa. (2014) . Pengembangan dan Implementasi Kurikulum 2013. Bandung: PT Remaja Rosdakarya.

Rusman. (2016) .Pembelajaran Tematik Terpadu (Teori, Praktik, dan Penilaian). Jakarta: PT Raja Grafindo Persada.

Sahardita, K. (2011). Efektivitas Penggunaan Teknik Permainan dalam Bimbingan Kelompok Untuk Meningkatkan Percaya Diri Siswa. Jurnal Pendidikan, Vol. 1. 127-138.

Sugiyono, (2014). Metode Penelitian Pendidikan Pendekatan Kuantitatif, Kualitatif, dan R\&D. Bandung: Alfabeta.

Trianto. (2011). Model Pembelajaran Terpadu Konsep, Strategi dan Implementasinya dalam Kurikulum Tingkat Satuan Pendidikan (KTSP), Jakarta : Bumi Aksara.

Yaumi, M. (2016). Pendidikan Karakter : Landasan, Pilar, dan Implementasi. Jakarta: Prenadamedia Group. 